\title{
HUBUNGAN PENGUKURAN RICHMOND AGITATION SEDATION SCALE (RASS) DENGAN KEBERHASILANWEANING VENTILATOR DI RUANG INTENSIF UPTD. RSUD BALI MANDARA PROVINSI BALI
}

\author{
The Relationship of The Richmond Agitation Sedation Scale (RASS) Measurement \\ with The Success of Weaning Ventilator in The Intensive Room Bali Mandara \\ Hospital, Bali Province
}

I Dewa Gede Pranata Wiguna

Prodi S1 Keperawatan, Stikes Bina Usada, Indonesia Korespondensi: I Dewa Gede PranataWiguna dan pranata101095@gmail.com

\begin{abstract}
ABSTRAK
Latar Belakang: Penyapihan dari ventilator mekanik dapat didefinisikan sebagai proses pelepasan ventilator baik secara langsung maupun bertahap. Salah satu cara untuk mengurangi kebutuhan ventilator adalah sedasi dan agitasi yang terukur dengan menggunakan skor Richmond Agitation and Sedation Scale (RASS). Tujuan Penelitian: Tujuan penelitian ini untuk mengetahui hubungan pengukuran Richmond Agitation Sedation Scale (RASS) dengan keberhasilan weaning ventilator di Ruang Intensif UPTD. RSUD Bali Mandara. Metedologi: Jenis penelitian ini observasional analitik dengan desain case control. Sampel penelitian ini berjumlah 48 responden dengan teknik consecutive sampling. Data dianalisis dengan uji Lambda untuk mengetahui hubungan antara pengukuran RASS dengan keberhasilan weaning ventilator dengan tingkat kemaknaan $\alpha=0,05$. Hasil: Hasil penelitian ini menunjukkan rata-rata usia responden $>65$ tahun yaitu 17 responden $(35,4 \%)$, sebagaian besar berjenis kelamin laki-laki yaitu 48 responden (62,5\%) sedangkan perempuan yaitu sebanyak 18 responden (37,5\%). Dengan skor RASS yaitu sedang sadar (0) dengan 22 responden (45,8\%), dengan tingkat keberhasilan weaning sebesar sebanyak 30 responden $(62,5 \%)$ dengan mode SPN CPAP dengan 16 responden $(88,9 \%)$ sementara kegagalan terjadi pada 18 responden $(37,5 \%)$. Analiss bivariat dengan uji Lambda menunjukkan bahwa nilai $\mathrm{p}$ sebesar 0.001 ( $\mathrm{p} \leq 0,05)$. Kesimpulan: Hal ini menunjukkan ada hubungan antara pengukuran Richmond Agitation and Sedation Scale (RASS) dengan keberhasilan weaning ventilator.
\end{abstract}

Kata kunci: Agitasi; sedasi; RASS; intensif; weaning ventilator.

\section{ABSTRACT}

Background: Weaning from a mechanical ventilator can be defined as the process of removing the ventilator either directly or gradually. One way to reduce the need fora ventilator is sedation and agitation measured using the Richmond Agitation and Sedation Scale (RASS) score. Objectives: This study purposed to determine the correlation between the measurement of the Richmond Agitation Sedation Scale (RASS) and the success of the weaning ventilator in the intensive room Bali Mandara Hospital. Methodology: This study was observational analytic with a case-control design. The research sample consisted of 48 respondents with a consecutive sampling technique. 
I Dewa Gede Pranata Wiguna: Hubungan Pengukuran Richmond Agitation Sedation Scale (Rass) dengan Keberhasilan Weaning Ventilator Di Ruang Intensif UPTD RSUD Bali Mandara

The data were analyzed by using the Lambda test to determine the correlation between the RASS measurement and the success of weaning the ventilator with a significance level of $\alpha=0,05$. Result: The results of this study indicate the average age of the respondents $>65$ years, namely 17 respondents $(35,4 \%)$, most of them were male, namely 48 respondents $(62,5 \%)$, while 18 respondents $(37,5 \%)$ were female. ). With the RASSscore, namely being aware (0) with 22 respondents $(45,8 \%)$, with a success rate ofweaning of 30 respondents (62,5\%) with the SPN CPAP mode with 16 respondents $(88,9 \%)$ while failure occurred in 18 respondents $(37,5 \%)$. The bivariate analysis with the Lambda test showed that the p-value was 0.001 ( $p \leq 0,05)$. Conclusion: This shows thatthere is a relationship between the measurement of the Richmond Agitation and Sedation Scale (RASS) and the success of the Weaning ventilator.

Keywords: Agitation; sedation; RASS; intensive; weaning ventilator.

\section{PENDAHULUAN}

Kegagalan

pernapasan meningkatnya mortalitas dan morbiditas. Data epidemiologi Sindrom Distres Pernapasan (ARDS)pada tahun 2016 dari 50 negara menunjukkan bahwa prevalensi ARDS sebesar 10,4\% dari total pasien rawat di Unit Perawatan Intensif (Intensive Care Unit/ICU). ARDS dapat terjadi pada seluruh usia, tetapi lebih sering terjadi pada pasien dewasa dan wanita. Di Amerika Serikat, 16 kasus per 100.000 populasi per tahun pada usia15-19 tahun dan 306 kasus per 100.000 populasi per tahun pada usia 75-84 tahun (Harman E, 2018). Menurut statistik AS, 55.000 pasien yang dirawat diruang ICU setiap harinya memiliki banyak alasan seperti Mechanical Ventilation (MV) atau alat bantu napas mekanik diperlukan pada lebih dari $90 \%$ pasien dewasa dengan penyakit kritis di ICU. Meskipun menyelamatkan nyawa puluhan ribu pasien dengan masalah oksigenasi, hal itu sekaligus menyebabkan banyak komplikasi dalam hal ini dikaitkan dengan angka kematian yang tinggi. MV jangka panjang lebih dari 3 hari, yang bisa meningkatkan biaya perawatan kesehatan, seperti biayaterkait penggunaan alat bantu napas mekanik dan kematian (Taran et al., 2019).

Bukan hanya terlambat menyapih pasien dari MV menyebabkan komplikasi, tapi penyapihan dini juga bisa mengarah ke intubasi dan intubasi ulang yang tidak direncanakan. Penelitian mendukung bahwa intubasi ulang meningkatkan kejadian pneumonia rumah sakit sebanyak delapan kali dan risiko kematian sebesar enam kali menjadi duabelas kali dibandingkan dengan saat pertama kali. Ekstubasi tidak terencana merupakan komplikasi utama dari tindakan endotrakeal intubasi yang dapat menghasilkan penggunaan ventilator dalam jangka panjang, hari rawat meningkat dan bahkan dalam beberapa kasus berujung kematian (Taran et al., 2019). Hal ini dapat disebabkan oleh pasien kurang kooperatif dan agitasi, atau pecahnya balon ETT secara tidak sengaja, batuk, atau penyebab lainnya. Berdasarkan kasus tersebut hal ini dapat menjadi bukti pendukung bahwa ekstubasi yang direncanakan dapat digunakan sebagai indeks kualitas keperawatan dan perawatan medis intensif di ICU (Cortés, 2011).

Pengelolaan analgesia serta sedasi di unit perawatan intensif memerlukan evaluasi dan juga parameter pemantau untuk mendeteksi 
I Dewa Gede Pranata Wiguna: Hubungan Pengukuran Richmond Agitation Sedation Scale (Rass) dengan Keberhasilan Weaning Ventilator Di Ruang Intensif UPTD RSUD Bali Mandara

Provinsi Bali

dan mengukur derajat rasasakit, agitasi, dan sedasi. Pengukuran skala tersebut memberikan gambaran dari rasa sakit, agitasi, dan sedasi yang berubah terusmenerus pada pasien kritis. Selanjutnya, pemantauan yang ketat memudahkan evaluasi ulang pada respon pasien terhadap terapi akan memudahkan evaluasi ulang pada respons pasienterhadap terapi (De Jonghe B, 2010)

Penelitian terhadap 975 pasien yang masuk Intensive Care Unit (ICU) dengan cara menilai hubungan antara skala RASS dan Sedation Agitation Scale (SAS) ditemukan angka korelasi koefisien yang tinggi, yaitu 0,91, dengan 30\% dariskala RASS memiliki skala -4 serta -5 (koma), 4,7\% dalam skala-1 hingga -3(sedasi), 62,6\% dalam skala 0 (tenang) dan $0,4 \%$ dalam skala +1 hingga +3 (agitasi)(Rinaldi $\mathrm{S}$, Consales G, 2006).

Menurut data dari studi pendahuluan yang dilakukan oleh peneliti sendiri, didapatkan jumlah pasien terawat dengan ventilator di ruang intensif RSUD Bali Mandara dari bulan Januari sampai Desember 2019 sebanyak 195 pasien dengan lama hari perawatan ventilator paling lama 35 hari. Dari 195 pasien didapatkan berhasil weaning sebanyak 123 orang dan sisanya 56 orang meninggal dan 56 lainnya di rujuk ke rs lain. Berdasarkan studi pendahuluan diatas dapat diketahui bahwa penggunaan ventilator sering terjadi dan berisiko dalam perawatannya. Dengan kondisi ini menunjukan bahwa perlu kajian kembali terhadap penilaian pasien selama proses perawatan ventilator dan mengaji keberhasilan proses wening/penyapihan terhadap ventilator tersebut.

Hal ini menunjukan peranan penting pengukuran RASS terhadap keberhasilan untuk Weaning ventilator dalam rangka mengurangi LOS (Length of Stay) pasien dan peningkatan mutu unit. Oleh karena itu peneliti tertarik untuk meneliti tentang Hubungan Pengukuran Richmond Agitation Sedation Scale (RASS) dengan keberhasilan Weaning ventilator di ruang intensif UPT. RSUD Bali Mandara Provinsi Bali.

\section{TUJUAN PENELITIAN}

Tujuan penelitian ini adalah untuk mengetahui hubungan pengukuran Richmond Agitation Sedation Scale (RASS) dengan keberhasilan weaning ventilator $\mathrm{di}$ ruang intensif UPT. RSUD Bali Mandara Provinsi Bali.

\section{METODE PENELITIAN}

Penelitian ini merupakan jenis deskriptif korelasional. Model pendekatan yang digunakan adalah cross-sectional, teknik pengambilan sampel dalam penelitian ini adalah consecutive sampling dengan jumlah total sampel dalam penelitia ini adalah 48 responden. Penelitian ini dilaksanakan September 2020 sampai dengan Januari 2021 di Ruang Intensif UPT. RSUD Bali Mandara Provinsi Bali.

\section{HASIL PENELITIAN}

Tabel 1. Karakteristik Responden Berdasarkan Usia

\begin{tabular}{lcc}
$\begin{array}{l}\text { Usia } \\
\text { (Tahun) }\end{array}$ & $\begin{array}{c}\text { Frekuensi } \\
\text { (f) }\end{array}$ & $\begin{array}{c}\text { Persentase } \\
(\%)\end{array}$ \\
\cline { 3 - 3 }$<35$ tahun & 4 & $8,3 \%$ \\
\hline $36-45$ tahun & 4 & $8,3 \%$ \\
\hline $46-55$ tahun & 13 & $27,1 \%$ \\
\hline $56-65$ tahun & 10 & $20,9 \%$ \\
\hline$>65$ tahun & 17 & $35,4 \%$ \\
\hline Total & $\mathbf{4 8}$ & $\mathbf{1 0 0 , 0} \%$ \\
\hline
\end{tabular}


I Dewa Gede Pranata Wiguna: Hubungan Pengukuran Richmond Agitation Sedation Scale (Rass) dengan Keberhasilan Weaning Ventilator Di Ruang Intensif UPTD RSUD Bali Mandara Provinsi Bali

Pada tabel di atas dari 48 responden dapat dilihat sebagian besar responden berumur

$>65$ tahun yaitu 17 responden $(35,4$ \%).46-55 tahun yaitu 13 responden $(27,1 \%)$, responden 56-65 tahun yaitu 10 responden $(20,9 \%)$, 36-45 tahun yaitu 4 responden $(8,3 \%)$, serta responden yang berumur $<35$ tahun yaitu 4 responden $(8,3 \%)$.

Tabel 2. Karakteristik Responden Berdasarkan Jenis Kelamin

\begin{tabular}{ccc}
\hline $\begin{array}{c}\text { Jenis } \\
\text { Kelamin }\end{array}$ & Frekuensi & $\begin{array}{c}\text { Persentase } \\
(\%)\end{array}$ \\
\hline Laki-laki & 30 & $62,5 \%$ \\
\hline Perempuan & 18 & $37,5 \%$ \\
\hline Total & $\mathbf{4 8}$ & $\mathbf{1 0 0} \%$ \\
\hline
\end{tabular}

Pada Tabel diatas dapat dijelaskan dari 48 responden dapat dilihat sebagaian besar responden berjenis kelamin laki-laki yaitu sebanyak 30 responden dari 48 responden $\quad(62,5 \%)$ sedangkan perempuan yaitu sebanyak 18 responden $(37,5 \%)$ dari 48 responden.

Tabel 3. Karakteristik Responden berdasarkan Parameter Setelah

Spontaneus Breathing Trial (SBT)

\begin{tabular}{|c|c|c|c|c|c|}
\hline Parameter & $\mathbf{N}$ & Min & $\begin{array}{c}\text { Ma } \\
\mathbf{x}\end{array}$ & Mean & Std. \\
\hline pH & 48 & 7,031 & $\begin{array}{l}7,5 \\
6 \\
1 \\
\end{array}$ & 7,38902 & $\begin{array}{l}0,107 \\
380\end{array}$ \\
\hline PO2 & 48 & 44 & 180 & 115,83 & 39,69 \\
\hline PCO2 & 48 & 21,1 & $\begin{array}{c}60, \\
2\end{array}$ & 37,661 & 8,733 \\
\hline $\begin{array}{l}\text { Tekanan } \\
\text { Darah }\end{array}$ & 48 & 67 & 165 & 117,92 & $\begin{array}{l}20,45 \\
2\end{array}$ \\
\hline Heart Rate & 48 & 60 & 145 & 96,63 & 18,99 \\
\hline $\begin{array}{l}\text { Respiratory } \\
\text { Rate }\end{array}$ & 48 & 14 & $\begin{array}{l}3 \\
5\end{array}$ & 19,65 & $\begin{array}{c}4,64 \\
2\end{array}$ \\
\hline Suhu & 48 & 32,0 & $\begin{array}{c}40, \\
0\end{array}$ & 36,552 & 1,227 \\
\hline Saturasi & 48 & 75 & 100 & 95,13 & $\begin{array}{c}5,97 \\
0\end{array}$ \\
\hline
\end{tabular}

\begin{tabular}{|c|c|c|c|c|}
\hline GCS Total 48 & 2 & $\begin{array}{l}1 \\
5\end{array}$ & 8,19 & $\begin{array}{c}4,75 \\
2\end{array}$ \\
\hline Midazolam 48 & 12 & 120 & 42,50 & 26,54 \\
\hline Propofol & 0 & $\begin{array}{l}48 \\
00\end{array}$ & 265,00 & 1020, \\
\hline Hemoglobin 48 & 5,9 & $\begin{array}{c}15, \\
0\end{array}$ & 11,605 & 2,112 \\
\hline Valid (N) $\quad 48$ & & & & \\
\hline
\end{tabular}

Pada tabel diatas dapat dijelaskan dari 48 responden dapat dilihat dari responden dari kadar $\mathrm{pH}$ rata-rata 7,38 dengan rentang 7,0317,561, kadar PO2 rata-rata 115.83 mmHgdengan rentang $44-180 \mathrm{mmHg}$, untuk kadar $\mathrm{PCO} 2$ rata-rata 37.661 dengan rentang 21.1-60.2 $\mathrm{mmHg}$, tekanan darah rata-rata 117,92 dengan rentang 48-165, nadi (heart rate) ratarata 96.63 dengan rentang 67-165 $\mathrm{x} / \mathrm{menit}$, frekuensi nafas (respiratory rate) rata-rata 19.65 dengan rentang 14$35 \mathrm{x} /$ menit, suhu rata- rata36.552 dengan rentang $32,00 \mathrm{C}-40,0 \quad 0 \mathrm{C}$, Saturasi O2 rata-rata 95.13 denganrentang $75 \%$-100 \%, GCS (Glasgow Coma Scale) total rata-rata 8.19 dengan rentang 2-15, Sedasi (Midazolam) rata-rata $42,50 \mathrm{mg} / \mathrm{hari}$ dengan rentang $12 \mathrm{mg}-120 \mathrm{mg} / \mathrm{hari}$, sedasi profofol rata-rata $265,00 \mathrm{mg} /$ hari dengan rentang $0-4800 \mathrm{mg} / \mathrm{hari}$ dan kadar hemoglobin rata-rata 11,840 dengan rentang 5,9-15,0g/dL. 
I Dewa Gede Pranata Wiguna: Hubungan Pengukuran Richmond Agitation Sedation Scale (Rass) dengan Keberhasilan Weaning Ventilator Di Ruang Intensif UPTD RSUD Bali Mandara Provinsi Bali

Tabel 4. Karakteristik Responden Berdasarkan Tata Cara Weaning Ventilator

\begin{tabular}{|c|c|c|c|}
\hline \multirow[t]{2}{*}{ Variabel } & \multicolumn{2}{|r|}{$\begin{array}{l}\text { Tata Cara } \\
\text { Penyapihan } \\
\end{array}$} & \multirow[b]{2}{*}{ T-Piece } \\
\hline & SIMV & $\begin{array}{lc}\text { PSV } & \text { SPN } \\
& \text { CPAP }\end{array}$ & \\
\hline $\begin{array}{l}\text { Jumlah } \\
\text { Pasien }\end{array}$ & $\begin{array}{c}5 \\
(10,4 \%)\end{array}$ & $\begin{array}{cc}11 & 18 \\
(22,9 \%)(37.5 \%)\end{array}$ & $14(29.2 \%)$ \\
\hline $\begin{array}{c}\text { Keberhasila } \\
\text { n }\end{array}$ & & & \\
\hline Berhasil & $0(0) \%$ & $\begin{array}{cc}2 & 16 \\
(18.1 \%) & (88,9 \%)\end{array}$ & $12(85,7 \%)$ \\
\hline Gagal & $\begin{array}{c}5 \\
(100 \%)\end{array}$ & $\begin{array}{cc}9 & 2 \\
(81,9 \%) & (11,1 \%) \\
\end{array}$ & $2(14,3 \%)$ \\
\hline Total & $\underline{5}$ & $\underline{11} \quad \underline{18}$ & $\underline{14}$ \\
\hline
\end{tabular}

Pada tabel diatas dapat dijelaskan dari 48 responden dapat dilihat responden yang berhasil dalam tata penyapihan terbanyak yaitu SPN CPAP dengan 16 responden $(88,9 \%)$ dari 18 responden, T-Piece dengan 12 Responden $(85,7 \%)$ dari 14 responden, PSV dengan 2 responden $(18,1 \%)$ dari 11 responden dan SIMV dengan 0 responden $(0) \%$. Hasil analisis data dari 48 responden dapat dilihat responden yang gagal dalam tata penyapihan terbanyak yaitu PSV dengan 9 responden $(81.9 \%)$ dari 11 pasien, SIMV degan 5 responden $(100 \%)$ dari 5 responden, SPN CPAP dengan $2(11,1 \%)$ dari 18 responden dan T-Piece dengan 2 responden (14.3\%) dari 14 responden.

Tabel 5. Karakteristik Responden Berdasarkan Skor Richmond Agitation And Sedation Scale (RASS)

\begin{tabular}{lcc}
\hline Variabel & F & $\mathbf{( \% )}$ \\
\hline \multicolumn{1}{c}{ Skor RASS Awal } & & \\
\hline tidak bisa bangun (-5) & 7 & 14,6 \\
\hline sedasi dalam (-4) & 23 & 47,9 \\
\hline sedasi sedang (-3) & 2 & 4,2 \\
\hline sedasi ringan (-2) & 5 & 10,4 \\
\hline Mengantuk (-1) & 2 & 4,2 \\
\hline tenang sadar (0) & 9 & 18,8 \\
\hline Total & $\mathbf{4 8}$ & $\mathbf{1 0 0 , 0}$ \\
\hline
\end{tabular}

\begin{tabular}{lcc}
\hline \multicolumn{2}{c}{ Skor RASS Akhir } & \\
\hline tidak bisa bangun (-5) & 9 & 18,8 \\
\hline sedasi dalam (-4) & 8 & 16,7 \\
\hline sedasi ringan (-2) & 3 & 6,3 \\
\hline mengantuk (-1) & 5 & 10,4 \\
\hline tenang sadar (0) & 22 & 45,8 \\
\hline gelisah (2) & 1 & 2,1 \\
\hline Total & $\mathbf{4 8}$ & $\mathbf{1 0 0 , 0}$ \\
\hline
\end{tabular}

Pada tabel di atas dari 48 responden dapat dilihat dari skor (Richmond Agitation and Sedation Scale) RASS awal dapat dilihat bahwa skor RASS terbanyakpada responden yaitu sedasi dalam (-4) dengan 27 responden $(47,9 \%)$ dari 48 responden, tenang sadar (0) yaitu 9 responden $(18,8 \%)$ dari 48 responden, tidak bisa bangun (-5) dengan 7 responden $(14,6 \%)$ dari 48 responden, sedasi ringan $(-2)$ yaitu 5 responden $(10,4 \%)$ dari 48 responden, sedasi sedang (-3) yaitu 2 responden $(4,2 \%)$ dan mengantuk (-1) yaitu 2 responden $(4,2 \%)$ dari 48 responden.

Sementara untuk nilai RASS akhir dari hasil 48 responden dapat dilihat bahwaskor RASS terbanyak pada responden yaitu sedang sadar (0)dengan 22 responden $(45,8 \%)$, tidak bisa bangun (-5) dengan 9 responden $(18,8$ $\%$ ), sedasi dalam (-4) dengan 8 responden $(16,7 \%)$, mengantuk (1) dengan 3 responden $(6,3 \%)$, dan gelisah (2) dengan 1 responden $(2.1 \%)$ dari 48 responden.

Tabel 6. Karakteristik Responden berdasarkan Keberhasilan Weaning

\begin{tabular}{ccc} 
& Ventilator \\
\hline & Frekuensi & $\begin{array}{c}\text { Persentase } \\
(\mathbf{\%})\end{array}$ \\
\cline { 3 - 3 } Berhasil & 30 & $62,5 \%$ \\
\hline Gagal & 18 & $37,5 \%$ \\
\hline Total & $\mathbf{4 8}$ & $\mathbf{1 0 0 , 0} \%$ \\
\hline
\end{tabular}


I Dewa Gede Pranata Wiguna: Hubungan Pengukuran Richmond Agitation Sedation Scale (Rass) dengan Keberhasilan Weaning Ventilator Di Ruang Intensif UPTD RSUD Bali Mandara Provinsi Bali

Pada tabel di atas dari 48 responden dapat dilihat responden yang berhasil weaning ventilator yaitu sebanyak 30 responden $(62,5 \%)$ dan yang tidak berhasil 18 responden $(37,5$ $\%)$.

Tabel 7. Hubungan Pengukuran Richmond Agitation And Sedation Scale (RASS) dengan Keberhasilan Weaning Ventilator

\begin{tabular}{|c|c|c|c|c|c|c|c|c|c|c|c|c|c|c|c|}
\hline & \multicolumn{2}{|c|}{$(-5)$} & \multicolumn{2}{|c|}{$(-4)$} & \multicolumn{2}{|c|}{$(-2)$} & \multicolumn{2}{|c|}{$(-1)$} & \multicolumn{2}{|c|}{ (0) } & \multicolumn{2}{|c|}{ (2) } & \multicolumn{2}{|c|}{ Total } & \multirow[t]{2}{*}{$\mathrm{p}$} \\
\hline & $\mathrm{F}$ & $\%$ & $\mathrm{~F}$ & $\%$ & $\mathrm{f}$ & $\%$ & $\mathrm{f}$ & $\%$ & $\mathrm{f}$ & $\%$ & $\mathrm{f}$ & $\%$ & $\mathrm{~F}$ & $\%$ & \\
\hline Berhasil & 0 & 0 & 0 & 0 & 2 & 4,2 & 5 & 10,4 & 22 & 45,8 & 1 & 2,1 & 30 & 62,5 & $\begin{array}{l}0,0 \\
01\end{array}$ \\
\hline Gagal & 9 & 18,8 & 8 & 16,7 & 1 & 2,1 & 0 & 0 & 0 & 0 & 0 & 0 & 18 & 37,5 & \\
\hline Total & 9 & 18,8 & 8 & 16,7 & 3 & 6,3 & 5 & 10,4 & 22 & 45,8 & 1 & 2,1 & 48 & 100 & \\
\hline
\end{tabular}

Pada tabel 7 menunjukkan bahwa dari 48 responden yang berhasil dalam weaning ventilator dengan skor RASS (-2) dengan 2 responden (4,2\%), berhasil weaning dengan skor RASS (1) dengan 5 responden $(10,4 \%)$, berhasil weaning dengan skor RASS (0) dengan 22 responden $(45,8 \%)$ dan berhasil weaning dengan skor RASS (2) dengan 1 responden $(2,1 \%)$. Sementara dari 48 responden yang gagal weaning dengan skor RASS (-5) dengan 9 responden (18.8\%), gagal weaning dengan skor RASS (-4) dengan 8 responden (16.7\%), gagal weaning dengan skor RASS (-2) dengan 1 responden $(2.1 \%)$.

Pada tabel 7 menunjukan analiss bivariat dengan uji Lambda menunjukkan bahwa nilai $\mathrm{p}$ sebesar $0.001(\mathrm{p} \leq 0,05)$. Hasil ini mengindikasikan bahwa Ho penelitian ditolak dan Ha diterima yang berarti ada Hubungan Pengukuran Richmond Agitation And Sedation Scale (RASS) dengan Keberhasilan Weaning Ventilator Di Ruang Intensif UPTD Rumah Sakit Bali Mandara.

\section{PEMBAHASAN}

Dalam tata cara penyapihan ventilator dan keberhasilan yang akan terjadi menurut teori untuk menentukan toleransi seorang pasien terhadap SBT dibutuhkan kombinasi antara penelitiannya menemukan parameter SBT. Jika beberapa kriteria dalam parameter tersebut ditemukan, maka hal tersebut merupakan indikasi bantuan ventilasi mekanik dihentikan.(Kusuma \& Atmajaya, 2015) Penilaian para tim dokter dan perawat di ruang Intensive Care Unit (ICU) penting untuk keberhasilan melakukan pelepasan ventilasi mekanik. Teknik-teknik penyapihan ventilasi mekanik mempunyai pertimbangan masingmasing (Harahap, 2016).

Hal ini di dukung hasil penelitian (Rosema Sari, 2017) dengan menggunkanan metode uji klinis terbuka acak terkontrol desain parallel menunjukan hasil penelitian keberhasilan weaning dengan metode SPN CPAP dengan 18 responden $(100 \%)$ dan metode T-Piece dengan hasil berhasil weaning 12 responden $(66,67 \%)$ dan gagal weaning dengan 6 responden $(33,3 \%)$ dari jumlah subyek penelitian adalah 36 pasien. Dalam penelitian Cekmen \& Erdemli, (2011) yang membandingkan T-piece dengan CPAP pada 40 pasien, menunjukkan bahwa CPAP memiliki kegagalan penyapihan ventilasi mekanik lebih rendah (15\%) dibanding T-piece $(25 \%)$. 
Molina- Saldarriaga et al., (2010) dalam penelitiannya yang membandingkan CPAP dan T-piece pada 50 pasien COPD dan dinilai selama 30 menit, menghasilkan keberhasilan CPAP 76\% sedangkan Tpiece $60 \%$. Hal berbeda ditunjukan dalam penelitian Harahap (2016), Penelitian ini mendapatkan hasil bahwa penyapihan ventilasi mekanik yang paling banyak dilakukan di ICU RSUP Dr. Hasan Sadikin Bandung melalui once daily trial of $\mathrm{T}$ piece dengan 22 responden (44\%) dengan 20 responden $(90,9 \%)$ berhasil weaning dan $2(9,09 \%)$ gagal dalam weaning dari jumlah subyek penelitian 50 responden.

Dari teori dan hasil penelitian serta dengan membandingkan dengan penelitian lain peneliti dapat dibuktikan bahwa penggunaan metode weaning ditentukan oleh masing- masing tim medis dengan keberhasilan mode SPN CPAP dan T-piece lebih baik dalam proses penyapihan ventilator dengan mempertimbangkan faktor-faktor lain yang mempengaruhi serta menentukan skala ukur untuk penggunaan metode yang lebih baik.

Hasil penelitian menunjukkan bahwa dengan analisis bivariat dengan uji Lambda menunjukkan bahwa nilai $\mathrm{p}$ sebesar $0.001 \quad(p \leq 0,05)$. Hasil ini menunjukan ada Hubungan Pengukuran Richmond Agitation And Sedation Scale (RASS) dengan Keberhasilan Weaning Ventilator Di Ruang Intensif UPTD Rumah Sakit Bali Mandara.

Menurut Ismaeil, et all (2014) kejadian gagal ekstubasi pada pasien yang tersedasi terjadi pada pasien dengan skor $>2$. Hal ini terjadi sebagai akibat dari belum berfungsinya sistem pernapasan dengan baik sebagai akibat dari pemberian sedasi. Sedangkan <-3 juga mengakibatkan penurunan kondisi dan gagal ekstubasi pasien akibat sedasi terlalu dalam.
Hasil penelitiandi dukung oleh penelitian oleh Deli et al., (2017), menunjukkan terdapat perbedaan rerata skor pengukuran sedasi dengan menggunakan RASS pada awal dan akhir dengan nilai significancy 0,001 dengan angka keberhasilan weaning ventilator terhadap 13 responden hingga mode SPN CPAP sebanyak 100 \%. Dari hasil teori, hasil penelitian dan membandingkan dengan penelitian lain, dapat dibuktikan bahwa pengukuran

Richmon Agitation and Sedation Scale (RASS) memiliki peranan dalam mengontrol sedasi dan agitasi yang terjadi pada pasien dengan alat bantu nafas atau ventilator, sedasi dan agitasi memiliki pengaruh yang besar dalam menentukan keberhasilan weaning ventilator yang pastinya juga perlu memperhitungkan faktor-faktor lain sehingga akan meningkatkan angka keberhasilan weaning ventilator dan mengurangi Length of Stay (LOS) dan angka mortalitas pada pasien yang terawat dengan ventilator.

\section{KESIMPULAN}

Ada hubungan pengukuran Richmond Agitation and Sedation Scale (RASS) dengan keberhasilan weaning ventilator di ruang intensif UPTD Rumah Sakit Bali Mandara.

\section{DAFTAR PUSTAKA}

M., Marsh, B., Melot, C., Pearl, R., Silverman, H., Stanchina, M., Vieillard- Baron, A., \& Welte, T. (2007). Weaning from mechanical ventilation. European Respiratory Journal, 29(5), 1033-1056. https://doi.org/10.1183/0903193 6.00010206

Cekmen, N., \& Erdemli, O. (2011). The comparison of the effects of Tpiece and CPAP on hemodynamic parameters, 
I Dewa Gede Pranata Wiguna: Hubungan Pengukuran Richmond Agitation Sedation Scale (Rass) dengan Keberhasilan Weaning Ventilator Di Ruang Intensif UPTD RSUD Bali Mandara

arterial blood gases and success of weaning. Bratislava Medical Journal, 112(9), 512-516.

Cortés, I. E. A. (2011). Weaning from mechanical ventilation. Anaesthesia, pharmacology, intensive care and emergency 1 , medicine A.P.I.C.E. Milano;, st ed. Italy: Springer.

Dawson, R., Fintel, N. V., \& Nairn, S. (2010). Sedation assessment using the Ramsay scale: Rachel Dawson and colleagues review the reliability of tools for assessing sedation and how these differ from methods of measuring consciousness. EmergencyNurse, 3(18), 18-20.

De Jonghe B, C. D. (2010). Using and understanding sedation scoring systems: a systematic review. Intens Care Med, 26, 275-85.

Deli, H., Arifin, M. Z., \& Fatimah, S. (2017).

Perbandingan

Pengukuran Status Sedasi

Richmond Agitation Sedation

Scale (Rass) Dan Ramsay

Sedation Scale (Rss) Pada

Pasien Gagal Nafas Terhadap

Lama Weaning Ventilator Di

Gicu Rsup Dr.Hasan Sadikin

Bandung. Jurnal Riset

Kesehatan, $6(1), \quad 32$.

https://doi.org/10.31983/jrk.v6i1 2837.

Epstein, S. K. (2014). Weaning from ventilatory support. Current Opinion in Critical Care, 15(1), 36-43.

https://doi.org/10.1097/MCC.0b $013 \mathrm{e} 3283220 \mathrm{e} 07$.

Feliciano DV, Mattox KL, M. E. (2010). Trauma Sixth Edition. New York: McGrawHill,.

Feng Y, et al. . (2011). Age, Duration of Mechanical Ventilation, and Outcomes of Patients Who Are
Critically Ill. Chest., 136: 759764.

Garriga M, Pacchiarotti I, Kasper S, Zeller SL, Allen MH, Vázquez G, et al. F. S.

B. (2016). Psychiatry Assessment and management of agitation in psychiatry. Expert Consensus. World J. Biol. Psychiatry Off. J. World, 17, 86-128.

Girard, T. D., ett all. (2008). Efficacy and safety of a paired sedation and ventilator weaning protocol for mechanically ventilated patients in intensive care (Awakening and Breathing Controlled trial): a randomised controlled trial. The Lancet, 371(9607), 126134.https://doi.org/10.1016/S01 40- 6736(08)60105-1

Hanifa, A. (2017). Hubungan Hipotermi dengan Waktu Pulih sadar Pasca General Anestesi di Ruang Pemulihan RSUD Wates. Jurnal Ilmiah Keperawatan, 2-3.

Harahap, Y. S. D. T. E. S. (2016). Gambaran Tata Cara dan Angka Keberhasilan Penyapihan Ventilasi Mekanik di Ruang Perawatan Intensif Rumah Sakit Dr. Hasan Sadikin Bandung. Jurnal Anestesi Perloperatif, 4(November), 10-12.

Harman E, P. M. A. M. (2018). Respiratory Distress Syndrome. 195:860-70.

Ismaeil, M. F., El-Shahat, H. M., El-

Gammal, M., \& S., \& Abbas, A. M. (2014). Unplanned versus planned extubation in respiratory intensive care unit, predictors of outcome. Egyptian Journal of Chest Diseases and Tuberculosis,63(1), 
I Dewa Gede Pranata Wiguna: Hubungan Pengukuran Richmond Agitation Sedation Scale (Rass) dengan Keberhasilan Weaning Ventilator Di Ruang Intensif UPTD RSUD Bali Mandara Provinsi Bali

Iwan P dan Saryono. (2010). Mengelola Pasien dengan Ventilator Mekanik. Jakarta: Rekatama,.

Khalil Y, Ibrahim E, Shabaan A, Imam M, Amany EL, B. (2012). Assesment of risk factors responsible for difficult weaning from mechanical ventilation in adults. Egyptian J Chest Dis Tubercul., 61, 159-66.

Kusuma, I. B., \& Atmajaya, I. N. (2015). Penyapihan ventilasi mekanik. Jurnal Kedokteran Universitas Udayana, 25, 42-47.

Marino P, L. . (2012). The ICU book: Analgesia and Sedation. Lippincott Williams \& Wilkins, 49, 938-66.

Martin, J. Heymann, A., Bäsell, K., Baron, R., \& Biniek, R., Bürkle, H., ... \& Spies,

C. (2010). Evidence and consensusbased German guidelines for the management of analgesia, sedation and delirium in intensive care- short version. GMS German Medical Science, 8.

Masturah, I. N. A. P. (2018). Metodologi Penelitian

Kesehatan. Pusat Pendidikan SDM Kesehatan: Badan Pengembangan Dan Pemberdayaan Sumber Daya Manusia Kesehatan.

McConachie I. (2011). Handbook of ICU therapy. Analgesia for the high risk patient. New York: Cambridge University Press; 4, 51-64.

Molina-Saldarriaga, F. J., Fonseca-Ruiz, N. J., Cuesta-Castro, D. P., Esteban, A., \& Frutos-Vivar, F. (2010). Spontaneous breathing trial in chronic obstructive pulmonary disease: continuous positive airway pressure (CPAP) versus T-piece. Medicina
Intensiva, 34(7), 453-458. https://doi.org/10.1016/j.medin.2 010.03 .007

Montoya, A., et all. (2011). Validation of the Excited Component of the Positive and Negative Syndrome Scale (PANSS- EC) in a naturalistic sample of 278 patients with acute psychosis and agitation in a psychiatric emergency room. Health Qual. Life Outcomes, 9, 18.

Notoadmodjo. (2010). Promosi Kesehatan, Teori dan Aplikasi (R. Cipta (ed.)).

Notoatmojo, S. (2012). Metodologi Penelitian Kesehatan. Yogyakarta: Rineka Cipta.

Nursalam. (2015). Metodologi ilmu keperawatan. Jakarta: Salemba Medika., edisi 4,

Nursalam. (2017). Metodologi Penelitian Ilmu Keperawatan. 4th edn. (S. Medika. (ed.)).

Prottengeier, J., Moritz, A., Heinrich, S., Gall, C., \& \& Schmidt, J. (2014). Sedation assessment in a mobile intensive care unit: a prospective pilot- study on the relation of clinical sedation scales and the bispectral index. Critical Care, 18(6), 615.

Rinaldi S, Consales G, D. G. A. (2006). Sedation monitoring in ICU. Curr Anaesth Crit Care., 17, 303-15.

Rosema Sari, A. C. F. R. W. U. W. (2017). Perbandingan Kegagalan Penyapihan Ventilasi. 4, 17-22.

Sastroasmoro, S. Ismael, S. (2011). Perkiraan Besar Sampel dalam Penelitian Klinis. Dasar-Dasar Metodologi Penelitian, 359.

Seisser N, Gossnell MS, Grap Mj, et all. (2013). The Richmond Agitation Sedation Scale: Validity and Reability in Adult Intensive Care Unit Patient. Am J Respir 
I Dewa Gede Pranata Wiguna: Hubungan Pengukuran Richmond Agitation Sedation Scale (Rass) dengan Keberhasilan Weaning Ventilator Di Ruang Intensif UPTD RSUD Bali Mandara

Crit. Med. : Reprinted American Thoracic Society, 166, 13381344. .

Setiadi. (2013). Konsep dan praktek penulisan riset keperawatan (Ed.2). Yogyakarta: Graha Ilmu, (Ed.2).

Smeltzer, S. C., \& Bare, B. G. (2013). Buku Ajar Keperawatan Medikal-Bedah Brunner \& Suddarth (12th ed.). EGC.

Sudjud, R. W., \& Yulriyanita, B. (2014). Sedasi dan Analgesia di Ruang Rawat Intensif Sedation and Analgesia In The Intensive Care Unit. 32, 221-233.

Sugiyono. (2013). Metode Penelitian Kuantitatif dan Kualitatif. Bandung: Alfabeta.

Taran, Z., Namadian, M., Faghihzadeh, S., \& Naghibi, T. (2019). The Effect of Sedation Protocol Using Richmond AgitationSedation Scale (RASS) on Some Clinical Outcomes of Mechanically Ventilated Patients in Intensive Care Units: a Randomized Clinical Trial. Journal of Caring Sciences, 8(4), 199-206. https://doi.org/10.15171/jcs.201 9.028

Young J. (2010). Sedation. Dalam: Core topics in critical care medicine. New York: Cambridge university press; 77- 88.

Yousefi, H., Toghyani, F., Yazdannik, A., \& Fazel, K. (2015). Effect of using Richmond Agitation Sedation Scale on duration of mechanical ventilation, type and dosage of sedation on hospitalized patients in intensive care units. Iranian Journal of Nursing and Midwifery Research, 20(6), 700.https://doi.org/10.4103/1735 - 9066.170008. 